\title{
Homo novus and nobilis: Cicero and the formation of the 'modern' aristocracy
}

\section{Introduction}

Cicero's novitas, “newness”, is well known to have had a significant influence on the creation of the portrait of the republican orator and statesman and its propagation throughout the centuries. Conscious of what being a novus homo meant in the turbulent years of the late Republic, Cicero tried to overcome his lack of famous ancestors by devising a strategy of self-advertisement and political advancement based on the exercise of personal virtues. Modern scholarship has long investigated the dichotomy between nobilis and homo novus, concentrating on Roman nobilitas, the class struggle and the role played by new men in Roman history and society. ${ }^{1}$ The excellent book of Henriette van der Blom has shed light on Cicero's discourse of novitas and his exploitation of historical and personal exempla to build up his public image of perfect orator and politician. ${ }^{2}$ Less attention has been paid to the impact exercised by Cicero homo novus on the birth and development of bourgeois values in later centuries. ${ }^{3}$ This paper revisits the role played by Cicero homo novus in the creation of a new ideal of nobility and argues that the status of Cicero as new man and new nobilis effected later reflections on human dignity and nobility throughout the Middle Ages and the Early Italian Renaissance. It starts by paying attention to Velleius Paterculus' celebration of the homines novi (2.126-130). As Velleius demonstrates, alongside Marius, the bearer and interpreter of the new ideology of leadership, as he displays himself in Sallust's fictional speech delivered before the Roman people after his election to consulship (Sall. Iug. 85), ${ }^{4}$ Cicero was held as the most representative example of political and rhetorical excellence, making up for his lack of ancestors by personal merits. Then, it reconsiders later receptions of Cicero's newness and the political re-use of Cicero's self-portrait as homo novus over the centuries. To

1 Wiseman 1971; Burckhardt 1990; see also Shackleton Bailey 1986; Günther 2006; van der Blom 2010. On Cicero's self-portrait as homo novus in his oratorical and rhetorical works, see Dugan 2005 (also Bishop 2019, 3-7). For the integration of men of municipal origins into the political system of the late Republic, see Santangelo 2019.

2 Van der Blom 2010.

3 Van der Blom 2018 (on Cicero homo novus in the early imperial period).

4 On Marius' speech in Sallust, see Yakobson 2014.

Ә OpenAccess. (C) 2022 Giuseppe La Bua, published by De Gruyter. (cc) BY This work is licensed under the Creative Commons Attribution 4.0 International License. https://doi.org/10.1515/9783110748703-008 
later generations Cicero was a figure of politician immediately associated to the notion of novitas and nobilitas attainable through moral virtues. Later biographers and intellectuals elaborated on the figure of Cicero, seen as the unsurpassed model of political man acting for the conservation of the res publica by virtus and ingenium. Cicero's successful strategy for political and social advancement challenged the public perception of nobilitas. What is most important, Cicero homo novus set up a model of credible politician, an exemplum to be followed and imitated by others.

\section{Velleius on Cicero as Icon of nobilitas}

In the so-called “Tiberian narrative”, the presentation of Tiberius' reign which occupies a large portion of the second book of his compendium of Roman history, Velleius Paterculus pays tribute to the homines novi of the past offered as exempla for new men longing for an active role in Roman political life (2.126130). ${ }^{5}$ In moralistic, Sallustian tones, Vellius expands on the nobilitas of homines novi, "new men" attaining honors through virtus, and celebrates Sejanus, raised to the rank of adiutor imperii, power assistant, as a paradigm of morality, a man neutralizing his lack of noble origins by personal merits. ${ }^{6}$ Within a general interpretation of human and Roman history in ethical terms, ${ }^{7}$ Vellius places emphasis on the virtus of the novi cooperating with the princeps in consolidating imperial power and points to the interrelationship between morality and politics as crucial to peace and political stability. ${ }^{8}$ In reminding his readers of the traditional, deep-rooted contest between patricians and new men in early and late Republic, he also endorses the equation of "noble man" and "best man", a trait regarded as characteristic of the ideal statesman. Velleius' passage reads as follows $(2.128 .1-4):^{9}$

In huius virtutum aestimatione iam pridem iudicia civitatis cum iudiciis principis certant; neque novus hic mos senatus populique Romani est putandi, quod optimum sit, esse nobilissimum. Nam et illi qui ante bellum Punicum abhinc annos trecentos Ti. Coruncanium,

5 Woodman 1977, 234.

6 For the portrait of Sejanus in Velleius, see Schmitzer 2000, 263-286.

7 Giazzi 2015 (on exemplarity and morality in Velleius' historiography). For Velleius' celebration of Roman values (especially in the praise of Tiberius' reign at 2.126.2-4), see Schmitzer 2011. A good discussion of virtus in Velleius' history is now in Balmaceda 2017, 129-156.

8 Woodman 1977, 256.

9 On this passage, see Woodman 1977, 255-262. For Velleius' use of pragmatic explanations based on historical exempla, see Marincola 2011, 131-132. 
hominem novum, cum aliis omnibus honoribus tum ium pontificatu etiam maximo ad principale extulere fastigium, et qui equestri loco natum Sp. Carvilium et mox M. Catonem, [2.] novum etiam Tusculo urbis inquilinum, Mummiumque Achaicum in consulatus, censuras et triumphos provexere, et qui C. Marium [3.] ignotae originis usque ad sextum consulatum sine dubitatione Romani nominis habuere principem, et qui M. Tullio tantum tribuere, ut paene adsentatione sua quibus vellet principatus conciliaret, quique nihil Asinio Pollioni negaverunt, quod nobilissimis summo cum sudore consequendum foret, profecto hoc senserunt, in cuiuscumque animo virtus inesset, ei plurimum esse tribuendum. [4.] Haec naturalis exempli imitatio ad experiendum Seianum Caesarem, ad iuvanda vero onera principis Seianum propulit senatumque et populum Romanum eo perduxit, ut, quod usu optimum intellegit, id in tutelam securitatis suae libenter advocet.

In the value set upon the character of this man, the judgment of the whole state has long vied with that of the emperor. Nor is it a new fashion on the part of the Senate and the Roman people to regard as most noble that which is best. For the Romans who, three centuries ago, in the days before the Punic war, raised Tiberius Coruncanius, a "new man", to the first position in the state, not only bestowing on him all the other honours but the office of pontifex maximus as well; and those who elevated to consulships, censorships, and triumphs Spurius Carvilius, though born of equestrian rank, and soon afterwards Marcus Cato, though a new man and not a native of the city but from Tusculum, and Mummius, who triumphed over Achaia; and those who regarded Gaius Marius, though of obscure origin, as unquestionably the first man of the Roman name until his sixth consulship; and those who yielded such honours to Marcus Tullius that on his recommendation he could secure positions of importance almost for anyone he chose; and those who refused no honour to Asinius Pollio, honours which could only be earned, even by the noblest by sweat and toil - all these assuredly felt that the highest honours should be paid to the man of merit. It was but the natural following of precedent that impelled Caesar to put Sejanus to the test, and that Sejanus was induced to assist the emperor with his burdens, and that brought the Senate and the Roman people to the point where they were ready to summon for the preservation of its security the man whom they regarded as the most useful instrument. ${ }^{10}$

The praise of Sejanus - and his famous predecessors - stems from a moral revisitation of the notion of nobilitas. Velleius breaks with the obsolescent category of nobility as associated to ancestry or noble lineage. The "most noble" is "the best", quod optimum sit, esse nobilissimum: ${ }^{11}$ reformulating a key concept of Marius' political manifesto, as it is illustrated in Sallust's celebrated speech, ${ }^{12}$ and

10 Text and translation of Velleius: Shipley 1955.

11 On this sententia and a brief excursus on the contrast between "the traditional nobilitas of the nobiles, dependent upon genus, and the nobilitas of the novi homines, attainable through virtus”, see Woodman 1977, 256-58.

12 Cf. Sal. Iug. 85.13: Quamquam ego naturam unam et communem omnium existimo, sed fortissimum quemquem generosissimum ("To be sure, I personally believe that all men have one and the same nature, but that the bravest is of the best stock"); cf. also 85.17: Quod si iure me des- 
following a tradition which links novitas with virtus ${ }^{13}$ Velleius demonstrates the vitality of a political system founded on the replication of the ancestral moral virtues and calls to mind new men of the past who have ascended the cursus honorum because of their moral and political virtues. Tiberius Coruncanius, Spurius Servilius, Cato, Mummius, Marius and, at the top of the list, the couple Cicero-Asinius Pollio, ${ }^{14}$ the first one eulogized as the politician acting on behalf of his fellow-citizens and clients, the second one exalted as a model of morality: ${ }^{15}$ all of them are presented as men achieving nobility by means of those virtues that render a Roman citizen a vir bonus, a true, good Roman citizen and, above all, a "true noble". ${ }^{16}$

Whatever the purpose of Velleius' praise of the novi, what matters here is that the Roman historian shows interest in portraying the ideal statesman, legitimated to power by labor and industria, operosity and diligence, whose status of authority emanates from moral and intellectual qualities. For Velleius virtus is "something personal, not a prerogative or an attribute of a social class". ${ }^{17}$ The Roman historian dreams of a restoration of the ancient customs and forms of the early Republic (2.89.3 prisca illa et antiqua rei publicae forma revocata). ${ }^{18}$ In trying to harmonize the idealized morality of the ancestors with new forms of political behavior, Velleius gets rid of the stereotyped image of nobility as exclusive to high-born individuals and pushes forward a new, reinvigorated idea of aristocracy. Virtus is a unifying concept in Roman history; it connects the "imperial present with the republican past". ${ }^{19}$ Models of political excellence, the "new men" play a key role in the creation of a political system in which the traditional antithesis between nobiles and homines novi is annihilated by virtus. Marius, the first, notable example of homo novus attaining consulship because of his merits,

piciunt, faciant idem maioribus suis, quibus, uti mihi, ex virtute nobilitas coepit ("But if they rightly look down on me, let them do likewise in the case of their own forefathers, whose nobility began, as does mine, from personal merit”). Latin text and English translation of Sallust: Rolfe-Ramsey 2013.

13 Cf. Cic. Sest. 136.

14 It might be observed that the list of novi, the new heroes and ancestors, peaks with Cicero and Asinius Pollio, a leading figure in the Augustan age, labelled as the "most hostile to Cicero's glory" (infestissimus famae Ciceronis) by Seneca the Elder (suas. 6.24).

15 On Asinius Pollio as model of virtue in Velleius, see Pistellato 2006.

16 For Velleius' moralistic vision of history, see Schmitzer 2011.

17 Balmaceda 2017, 137.

18 Hillard 2011, on Velleius' effort to harmonize political tradition and innovation.

19 Balmaceda 2017, 141. 
Cicero and Asinius Pollio testify to the centrality of virtus to the intellectual and moral formation of the individual. ${ }^{20}$

It might be tempting to say that, by claiming superiority on moral grounds and providing examples of men compensating the disadvantages of novitas by personal qualities, Velleius subscribes to a progressive, revolutionary ideology. Yet the historian does not aim to subvert ancient Republican institutions. He sees Roman history as a continuum and interprets the advent of the principate as the final point of a long historical process in which virtus occupies a central place. For Velleius, the novi, like Sejanus (and himself), may contribute to the realization of the ideal Roman state, intended as "a stage for virtus". ${ }^{21}$ Velleius' archetypical new man acts for the safety of Roman citizens and the restoration of the ancient Roman values. He ennobles his novitas because of his personal virtues. From this perspective Cicero homo novus, the republican orator and statesman who downplayed the importance of ancestry and preserved the republican institutions by virtus and loyalty, incarnates the values and ideology of "modern" nobility. Velleius' celebration of Cicero's consulship and the suppression of the Catilinarian conspiracy is an eloquent passage (2.34.3-4):

Per haec tempora M. Cicero, qui omnia incrementa sua sibi debuit, vir novitatis nobilissimae et ut vita clarus, ita ingenio maximus, quique effecit, ne quorum arma viceramus, eorum ingenio vinceremur, consul Sergii Catilinae Lentulique et Cethegi et aliorum utriusque ordinis virorum coniurationem singulari virtute, constantia, vigilia curaque aperuit. [4.] Catilina metu consularis imperi urbe pulsus est; Lentulus consularis et praetor iterum Cethegusque et alii clari nominis viri auctore senatu, iussu consulis in carcere necati sunt.

At this time, the conspiracy of Sergius Catiline, Lentulus, Cethegus, and other men of both the equestrian and senatorial orders was detected by the extraordinary courage, firmness, and careful vigilance of the consul Marcus Cicero, a man who owed his elevation wholly to himself, who had ennobled his lowly birth, who was as distinguished in his life as he was great in genius, and who saved us from being vanquished in intellectual accomplishments by those whom we had vanquished in arms. Catiline was driven from the city by fear of the authority of the consul; Lentulus, a man of consular rank and twice a praetor, Cethegus, and other men of illustrious family were put to death in prison on the order of the consul, supported by the authority of the senate.

Opposing members of illustrious family Cicero ennobled his novitas by displaying his powerful ingenium and his extraordinary political abilities. ${ }^{22}$ Velleius

20 Brescia 2011. On Velleius' designation of Marius as Romani nominis princeps and the re-establishment of the notion of Roman identity as crucial to the conservation of the res publica, see Cowan 2011.

21 Balmaceda 2017, 156.

22 Keeline 2018, 162-163. 
homo novus looks at Cicero as a symbol of a political system in which moral rectitude and natural talents represent the real key to success. ${ }^{23}$ This celebration of Cicero's novitas sheds also light on the conclusion of Velleius' passage, in which the Roman historian illustrates Tiberius' politics and points to the notion of natural 'imitation' of the best examples (naturalis imitatio) as fundamental to the princeps' choice to invest his assistant with special powers. Sejanus, like his past, illustrious antecedents, is seen as an outstanding example of notable virtue; he embodies the supremacy of good intellect over the traditional equation of aristocratic origins and morality. ${ }^{24}$ And, in turn, by valorizing ingenium and natural skills in opposition to family traditions and achievements the optimus princeps acts as an exemplum to be followed by others. ${ }^{25}$ To put it in different terms, Velleius encourages Tiberius to adopt and propose a policy promoting moral and political excellence.

\section{Becoming a 'new man' and a good politician}

As we have seen, by endorsing Cicero's redefinition of his own newness, Velleius, a devoted admirer of the republican orator, ${ }^{26}$ contributed to create the image of the ideal statesman, compensating for his novitas through the construction and propagation - of a public persona. Cicero's self-fashioning, as both homo novus and ideal politician, his life and, above all, his political triumphs served as proof of how ingenium, good intellect, and bene facta, good deeds, could lead men of humble origins to the acquisition of a status of authority within Roman élite society. Cicero's auctoritas also provided later generations with a powerful example of political behaviour to be adopted by other new men. As Gruen notes, "Cicero was a novus homo, but no ordinary novus homo". Cicero's astonishing achievements acted as a stimulus and encouragement for men lacking aris-

23 Cf. also the eulogistic portrait of Agrippa at 2.96.1: Mors deinde Agrippae, qui novitatem suam multis rebus nobilitaverat ("Then occurred the death of Agrippa. Though a new man he had by his many achievements brought distinction upon his obscure birth”). See Woodman 1983, 198199; Wiegand 2013, 137.

24 On the portrait of Sejanus in Velleius, "a guarded praise" and "more a defense of Tiberius than a panegyric for Sejanus”, see Marincola 2011, 132 (and n. 38 for further bibliography). 25 Vell. 2.126.3: Nam recte facere cives suos princeps optimus faciendo docet, cumque sit imperio maximus, exemplo maior est ("For the best of emperors teaches his citizens to do right by doing it, and though he is greatest among us in authority, he is still greater in the example which he sets").

26 Cf. Vell. 2.66.4-5, for the celebration of Cicero's intellect and eloquence: see Woodman 1983, 144-155; Schmitzer 2000, 184-189. 
tocratic origins and "a new generation of aspiring orators also found Cicero attractive". 27

In presenting himself as an example of nobilissima novitas, a new man capable of contesting traditional nobilitas and achieving political and rhetorical success by his merits, Cicero provided his fellow-citizens and generations to come with a modern figure of statesman. He embodied an idea of nobility depended upon the exercise of virtus. It is well known that Cicero aspired to become a model of Latin prose, the center of an educational program founded on the knowledge of good Latin. ${ }^{28}$ At the same time, Cicero longed to be the supreme model of homo novus and "best man", the true nobilis achieving success through moral virtues and political abilities. Novitas and nobilitas were catchwords in Cicero. He placed himself at the very outset of a tradition that regarded intellect and personal skills as crucial to social and political success.

As expected, Cicero's newness and his self-fashioning as novus nobilis were major targets for criticism and condemnation from political enemies, as Cicero himself makes it clear on several occasions. ${ }^{29}$ Not only during his lifetime, but also (and much more) after his assassination Cicero's self-construction as homo novus - and his revolutionary idea of nobilitas - ignited fierce debate on the notion of Romanitas, at the same time eliciting reflections on issues of cultural identity and the (violent) transition from the Republic to the principate. ${ }^{30}$ Cicero, as both a man and politician, was a very controversial figure. Later responses to Cicero oscillated between praise and blame, as clearly showed by recent studies. ${ }^{31}$ Cicero's rhetoric of newness was a key topic in later presentations of his political image. Additionally, it should be noted that the flexibility of the term nobilitas and the related ambiguity in its ideological and political use had consequences on the creation of a new, "Ciceronian" ideology of novitas. Seneca the Younger, fluctuating between deprecation of genealogical connections as guarantees of nobility (epp. 44; 76; Ben. 3.28) and praise of nobilitas as emanation of past aristocracy (Ben. 4.30.1), ${ }^{32}$ shows how unstable the relationship between past and present, morality and politics, continued to be still in the early imperial times.

27 Gruen 1974, 138-139.

28 La Bua 2019, 125-162.

29 On Cicero's deployment of the term homo novus and nobilis in his speeches and the rhetorical-political manipulation of the notion of novitas, see van der Blom 2010, 35-59.

30 Dench 2013, 130 - 134.

31 Gowing 2013; see also La Bua 2019, 100 - 112.

32 Costa 2012. 
Starting with the pseudo-Sallustian Invectiva in Ciceronem ([Sall.] Inv. 4.1), a text originated in the declamatory classrooms, it is easy to see that Cicero's selfpromotion as consul and homo novus represented a favorite theme of the antiCiceronian propaganda. ${ }^{33}$ Controversy raged over Cicero "new man" reaching the summit of cursus honorum with his consulship. Polemically labelled peregrinus ("foreign", a new man from Arpinum), Cicero was constantly referred to as a "non-Roman", a man accitus ("imported from abroad") and aspiring to become a new "king" of Rome. ${ }^{34}$ Without claiming, in a few lines, to trace the history of the ancient diatribe over Cicero's novitas, it is sufficient here to draw attention to Juvenal' Satire 8, a celebration of Cicero's ideology of novitas built upon the antithesis between Cicero and Catiline and the exemplary contrast between the unworthy noble and the worthy non-noble. Defined as a sort of compendium of earlier treatments of the theme of the nature of true nobility, ${ }^{35}$ the satire describes Cicero's triumph over the noble conspirators and culminates in a comparison between Cicero's toga and Octavian Augustus' warfare (8.231-44): ${ }^{36}$

Quid, Catilina, tuis natalibus atque Cethegi inveniet quisquam sublimius? arma tamen vos nocturna et flammas domibus templisque paratis, ut bracatorum pueri Senonumque minores, ausi quod liceat tunica punire molesta.

Sed vigilat consul vexillaque vestra coercet. hic novus Arpinas, ignobilis et modo Romae municipalis eques, galeatum ponit ubique praesidium attonitis et in omni monte laborat. tantum igitur muros intra toga contulit illi 240 nominis ac tituli, quantum in Leucade, quantum Thessaliae campis Octavius abstulit udo caedibus adsiduis gladio; sed Roma parentem, Roma patrem patriae Ciceronem libera dixit.

What ancestry more exalted than yours, Catiline, or that of Cethegus can be found? Yet you plotted to attack homes and temples at night and set them on fire, like the sons of trousered Gauls and descendants of the Senones, committing an outrage which could lawfully be punished by the uncomfortable shirt. But the consul is alert; he halts your banners. He - a new man from Arpinum, of humble origin, a municipal knight new to Rome - posts helmeted troops all around to protect the terrified people and is busy on every hill. So, with-

33 Cf. also Asc. 93.25C-94.6C (with the commentary of Lewis 2006, 304); schol. Bob. 80.11-23 Stangl.

34 [Sall.] Inv. 1; cf. also Sall. Cat. 31.7 (for the use of the term inquilinus civis urbis Romae). See Keeline 2018, 152-158.

35 Braund 1988, 98 (122-29, for a list of ancient sources on the theme of true nobility). 36 On Juvenal's passage, see Di Matteo 2014, 241-252. See also Courtney 1980, 368-369. 
out stepping outside the walls, his peacetime toga brought him as much titled distinction as Octavius grabbed for himself at Leucas and on the fields of Thessaly with his sword wet from nonstop slaughter. The difference is that Rome was still free when she called Cicero the Parent and Father of his Native Land. ${ }^{37}$

In the form of rhetorical suasoria, Juvenal mocks the degeneracy of contemporary nobilitas and encourages Ponticus, the addressee of the satire and a representative of aristocrats' vanity, to follow the illustrious example of Cicero. The satirical target is obviously the idea of nobility founded on aristocratic origins. ${ }^{38}$ Cicero's remarkable achievements, his strenuous defence of the free res publica against Catiline's and Cethegus' conspiracy, illustrate the very nature of true nobility. Cicero homo novus has been given the title of parens and pater patriae, "Father of Fatherland", thanks to his virtus. ${ }^{39}$ Positioning himself at the end of a long process of historical revisitation of the ideology of novitas, Juvenal satirizes and makes fun of nobiles claiming privileges and supremacy on blue-blooded origins and offers Cicero as undisputable example of true nobilis, a man facing up to the absence of noble ancestors by his unsurpassed moral and political qualities.

Juvenal's hyperbolical and sarcastic description of the vacuous symbols (stemmata) of the nobiles is far from being a moralistic attack (in Senecan terms) against the contemporary decadence of Roman aristocratic society. However ironic it might be, the satirist's praise of Cicero as a paradigm of nobilitas is of the greatest significance to our discussion. With his eulogistic presentation of Cicero homo novus and consul Juvenal contributes to the formation of a new humanism, political and social at the same time, centered on the notion of true nobility as dependent upon virtus. As has been noted, from the early imperial times onwards intellectuals and philosophers elaborated on the image of Cicero homo novus who created his own persona of true noble through a literary process of self-fashioning and self-configuration. A new canon of "new men" and "noble men", not limited to politicians, was established upon Cicero as model. Seneca the Younger, Tacitus, Paulus, and Augustine, are all good examples of men experiencing an 'anthropological transformation' and fashioning themselves as men of virtue. If it is true that "Cicero's self-presentation as a homo novus simply lost out in the competition with Cicero's exemplarity as an orator and a philoso-

37 Latin text and translation: Braund 2004.

38 On Juvenal's humorous depiction of the contemporary aristocrats, see Fredericks 1971.

39 For a parodic approach to Cicero's figure, especially in the allusions to the apologetic poem De consulatu suo, see Winkler 1988, 86-87. See also Uden 2015, 126-128. 
pher", ${ }^{40}$ it is an undeniable fact that Cicero's rhetoric of newness, his aspiration to be a model of new man and new noble putting his qualities at the service of the community, had a profound impact on the formation of new political classes and the creation of a modern idea of nobilitas.

\section{Cicero homo novus in the Middle Ages and the Early Italian Renaissance}

It is a well-known fact that the $13^{\text {th }}$ and $14^{\text {th }}$ centuries witnessed a revival of interest in Cicero's writings, his philosophical and political treatises, regarded and used as handbooks, instruction manuals for men seeking for an active role in social and political life. Cicero's ideal of the otium cum dignitate was a key point of what has been called the Roman civic spirit in the Early Italian Renaissance. As Baron explains, "in the second half of the thirteenth and during the fourteenth century the civic world of the Italian city-states came to the fore in European culture, and in this civic world Cicero was soon to become a most important guide in moral life, as he had been in the monastic humanism of the twelfth century". ${ }^{41}$

This resurgence of interest in Cicero's political works was not separated from a renovated attention to the biography of the man from Arpinum. As recently noted, we do not know of biographical works on Cicero in the medieval times and limited information about the life of the orator were usually included in the medieval accessus, introductions to Cicero's texts in the manuscripts. ${ }^{42}$ Celebrated as a cultural figure and teacher of virtue, as it can be seen in the mid- $13^{\text {th }}$ century Speculum historiale of Vincent de Beauvais, ${ }^{43}$ Cicero as a man was of little or even of no interest for intellectuals concerned with the moral education of young readers. The first, significant change of perspective seems to occur in the early fourteenth century with the anonymous epitome of Cicero's life, titled $<E p$ ithoma $>$ de vita gestis scientie prestancia et libris ac fine viri clarissimi et illustris Marchi Tullii Ciceronis, a biography prefaced to a consistent collection of Cicero's philosophical and rhetorical works in the Troyes manuscript (Troyes, Bibl. Mun., ms. 552, ff. 120r-122v), probably written around 1330 and containing marginalia

40 Van der Blom 2018, 287.

41 Baron 1938, 84.

42 Cook 2009.

43 Cook 2009, 349-351. 
from the hand of Petrarch (who acquired the manuscript in the early 1340s). ${ }^{44}$ From its very outset the unidentified composer attracts attention to Cicero's novitas, compensated by the power of intellect, and indicates Sallustius as his source (f. 120r):

\begin{abstract}
Marcus Tullius Cicero Arpinas equestris ordinis et matre Elvia ex regione Volscorum ortus est ut tradit Eusebius in cronicis. In commentis habetur quod pater ex equestri ordine ac regione prefata faber ferraius fuit. Unde Salustius dicit eum fuisse hominem novum hoc est infimi generis et quamquam in scolis pauperimus sua tamen sapientia patris inopiam superavit adeoque bone indolis extitit ut quod nulli plebeio erat licitum ipse sibi acquisiverit proprium, scilicet quod inter filios nobilium liberales didicit artes.

Tullius Cicero, man from Arpinum, knight, was born from Helvia in the Volscian region, as Eusebius says in his chronicles. From fictional stories we know that his father, a knight from the same region, was a blacksmith. So, Sallust says that Cicero was a new man of humble origins; though the poorest in the school, he overcame his father's lack of substance because of his knowledge. His character and qualities distinguished him from the others so that he obtained things and honours not permitted to the plebeians. He learned the liberal arts along with the sons of the nobles. ${ }^{45}$
\end{abstract}

Again, echoing Sallust's and Juvenal's words ${ }^{46}$ in the reconstruction of the Catilinarian conspiracy and the consulship the author of the epitome dwells on the traditional motif of the invidia Ciceronis and reiterates the opposition between the conspirators, noble and morally depraved, and Cicero, non-noble and reaching the pinnacle of his political career because of his merits:

Causa autem precipua collati consolatus hec fuit: patefacta siquidem Catiline, viri genere nobilis magnaque vi animi et corporis sed malo ingenio prelioque fulti, suorumque complicum execrabili coniuratione, ea res in primis Romanorum accendit studia ad conferendum Tullio consulatum. Nam antea multi nobiles contra eum invidia estuabant et quasi pollui consulatum credebant si eum homo novus fuisset adeptus. Sed ibi [sic] advenit periculum instantis, videlicet propalate coniurationis, postpositis invidia atque superbia habitisque comiciis Cicero et Anthonius declarati sunt consules. ${ }^{47}$

This was the reason by which Cicero was declared consul: when the execrable conspiracy planned by Catiline, man of noble origins filled with greatness of mind and body, though wicked and warmonger, and his followers was disclosed, the Roman people, whose resentment was stirred by this event, was eager to entrust the consulship to Cicero. In fact, before these many aristocrats were seething with jealousy; they thought that the consulship was polluted if a new man should attain it. But when danger was at hand and the conspiracy

44 Tilliette 2003, 1052; Cook 2009, 363.

45 My translation.

46 The words of the epitomator reproduce Sall. Cat. 23.

47 Tilliette 2003, 1066. 
was disclosed, jealousy and pride took second place: Cicero and Antonius were elected consuls after regular assemblies.

Though partial and unsystematic in the assemblage of biographical materials, the epitome deserves credit for addressing significant questions of Cicero's political life, his newness in primis. As Cook puts it, "the epitomator is on the track of recovering some of the most important information about Cicero and his day". 48 In trying to depict Cicero as a "living man", not just as an abstraction or the personification of good eloquence, the anonymous author of the Troyes epitome brings to the fore issues that are critical to Cicero's biographical tradition. For the first time since early empire, Cicero returns to be a historical figure, a man filled with ingenium who acted for the preservation of the republican institutions and embodied the ideals of the rising political class of the "new nobiles".

In addition to being a step forward the creation of a tradition of biographical studies on the figure di Cicero, the Troyes epitome was also of the greatest significance to Petrarch's scholarly work. In correcting the errors contained in the epitome (as far as we know from the marginalia in the manuscript) Petrarch filled some gaps in the tradition and took a stance on many critical questions in Cicero's life. His reconstruction of Cicero's life was fundamental to the formation of a new paideia and a modern cultural system founded on the preservation of the moral values of the past. Yet it should be remembered that for Petrarch Cicero was not a moral exemplum. The discovery of Cicero's letters left Petrarch surprised and disappointed, as they illuminated Cicero's internal contradictions and revealed his inability to practice a philosophical life. ${ }^{49}$ Similarly to what happened in the early empire criticism, Petrarch deplored Cicero's involvement in the world of politics. Following Petrarch not a few humanists called into question Cicero's personal deeds, within a larger debate about the superiority of the sage and philosopher over the man engaged in active political life.

Leonardo Bruni's Cicero Novus, composed in 1413 as a reaction to Jacopo Angeli's Latin translation of Plutarch's Cicero, ${ }^{50}$ is the first modern biography of Cicero and may be regarded as a foundational moment in the recovery and rebirth of Cicero as a historical figure..$^{51}$ In the footsteps of Brunetto Latini's re-evaluation of Cicero, Bruni provided an entirely positive image of Cicero, dismissing censures of his personality as philosopher and statesman and stressing his de-

48 Cook 2009, 360.

49 Eisner 2014, 759-765. For Cicero and Petrarch, see also Marsh 2013, 306-307. On Petrarch's discovery of Cicero's rhetoric of intimacy, see Eden 2007.

50 Cook 2013.

51 On Bruni's humanism and his historiography, see Fryde 1983, 33-53; Ianziti 2012. 
votion to the ideal of the concordia ordinum. Tracing the development of Cicero's life and political career, from the humble origins to the heroic death, Bruni considered the incident of the Catilinarian conspiracy as the zenith of Cicero's fortune, as it was in this very occasion that the designed consul preserved the civic community from the tyrannical power. Not only in the vita activa, but also in the vita contemplativa, i.e., in philosophical and literary writings, Cicero was a man of outstanding and exceptional ability. To Bruni's eyes, Cicero balanced the negative aspects of his later political life with the magnificence of his literary works. Quite eloquent are Bruni's final considerations on the human and political history of the man from Arpinum, placed as a preface to the detailed description of Cicero's literary output (p. 468 Viti):

\begin{abstract}
Homo vere natus ad prodessendum hominibus vel in re publica vel in doctrina: siquidem in re publica patriam consul, et innumerabiles orator servavit. In doctrina vero et litteris non civibus suis tantum sed plane omnibus qui latina utuntur lingua lumen eruditionis sapienteque aperuit [...] Hic ad potestatem romani imperii dominam rerum humanarum eloquentiam adiunxit. Itaque non magis patrem patrie appellare ipsum convenit, quam parentem eloquii et litterarum nostrarum.

He was a man born to contribute to the safety of the people in both politics and learning, as he preserved the country as consul and saved many as orator. In learning as well as in literary studies he offered the light of erudition and science not only to his fellow-citizens but also to all those who use the Latin language. [...] To the Roman imperial power, he added eloquence that dominates all the human things. Thus, it is appropriate to call him the father of his country no less than the father of Roman eloquence and literature. ${ }^{52}$
\end{abstract}

Bruni's Cicero is a political hero. Reworking and rewriting Plutarch's biography, ${ }^{53}$ Bruni, a representative of civic humanism, distanced himself from the prevalent moralistic tones of the biographical tradition to concentrate on the impact of Cicero as a historical and political figure on the life of the modern res publica. As Ianziti notes, “whereas Plutarch had emphasized Cicero's moral failings as the cause of his tragic downfall, Bruni built up a different picture. He chose to focus instead on Cicero's skills in navigating the political turmoil that had marked the end of the Roman Republic." 54 What emerges from Bruni's socio-political and intellectual biography is the image of a man who dominated the political scene of Republican Rome by his eloquence and powerful ingenium. In Bruni's Cicero we find the perfect synthesis of politics and culture, the incarnation of the ideal Renaissance humanist.

52 My translation.

53 Cook 2012. On the reception of Plutarch's Lives in the Florentine Humanism, see Pade 2007. 54 Ianziti 2012, 302. 
Bruni paved the way for later receptions of Cicero as a political figure in the Humanistic Renaissance. From Bruni onwards Cicero was to become a paradigm of political man: his historical achievements stimulated discussions about the role of intellectuals and statesmen in human and socio-political life. Within this broader context it is interesting to evaluate the impact exercised by Cicero's rhetoric of newness and nobilitas on the humanistic debate about the nature of true nobility, a central topic in the times of social and political transformations of the early modern state. ${ }^{55}$ Touched upon by Boethius and treated by Dante and Boccaccio, ${ }^{56}$ the theme of nobility inspired the composition of De dignitatibus by the fourteenth-century jurist Bartolo from Sassoferrato and the fictitious dialogue De nobilitate by Buonaccorso da Montemagno (c. 1428). In 1440 Poggio Bracciolini penned his De vera nobilitate (Poggii Florentini Ad Reverendissimum Patrem Dominum Cardinalem Cumanum Libellus De Vera Nobilitate), a neo-Ciceronian dialogue in which Niccolò Niccoli's Platonic view on nobility as founded on the exercise of virtue and wisdom is compared and contrasted with Lorenzo de' Medici's ideology of nobility as resulting from ancestry, wealth and political virtues. ${ }^{57}$ Again, the Stoics' view of nobility relying on learning rather than lineage is the central idea of Cristoforo Landino's Platonic dialogue De vera nobilitate, composed between 1485 and $1487^{58}$

To devote our attention to Poggio Bracciolini's dialogue, a text patently embedded in the social-political life of the city-state, both the contenders support their arguments by relying on the 'Cicero-paradigm'. ${ }^{59}$ Lorenzo de' Medici, defensor of the ideology of nobility as founded on the practical emulation of the virtues of the ancestors, celebrates Cicero (together with Marius) as example of man not ennobled by his origins but ennobling himself and his social class by his achievements: because of his deeds he paved the way for ennoblement of the equester ordo (principium generis nobilitandi), bestowing a legacy of virtues on his sons and generations to come (C. Marium et Marcum Tullium non nobilitavit genus, at hi suis filiis, si paternam virtutem imitari voluissent, insignem nobilitatem reliquere, §35: 18 Canfora). Later, responding to Niccolò Niccoli who advances the abstract, Stoic ideal of nobility as based on the pure exercise of personal vir-

55 On the Quattrocento debate over nobility, see Rabil 1991 (also Rabil 1988, 3.288-291). See also Donati 1988 and Jorde 1995.

56 Boeth. cons. phil. 3.6; Dante convivio III, pr. IV; mon. II 3. Hastings 1975, 86.

57 Edition: Canfora (D.) 2002. See Castelnuovo 2009; Finzi 2010 (also Jorde 1995, 77-91).

58 Edition: Liaci 1970. On the role played by Landino in the debate, see Jorde 1995.

59 Finzi 2010, 342-348. See also Celenza 2017, 152-156. Jorde 1995, 78, notes that "die eigentliche Kontroverse zwischen Niccolò und Lorenzo ist nach Ciceros Vorbild in einen ansprechenden szenischen Rahmen eingebettet”. 
tus, as demonstrated by the illustrious examples of Cato and Marius (§§ 66-67), ${ }^{60}$ Lorenzo elevates Cicero homo novus to nobilis and model worthy of emulation by exploiting a passage from the Pro Sestio (§ 136). Here Cicero's encouragement to the young to emulate the noble deeds of the maiores serves Lorenzo's ideology of true nobility as centered on the replication of the virtuous actions of the illustrious ancestors (§ 78):

\begin{abstract}
Nullo enim pacto negandum est paternam nobilitatem migrare in filios et esse et dici nobiles quorum nondum virtus est cognita. Hoc et sentit Cicero in oratione quam pro Sextio scripsit inquiens: "vosque adolescentes, qui nobiles estis, ad maiorum vestrorum imitationem excitabo". Vult sapientissimus Cicero etiam illos nobiles esse, qui nondum per etatem paternarum virtutum imitatores esse potuerunt. Atqui - loquar enim quod sentio - citius appellabo nobilem qui excellentis parentes potest referre, ipse vel paululum virtute ornatus, quam qui obscuris maioribus extiterit omni virtutum genere excellens.

In fact, no one can deny that the nobility of the ancestors is transferred into the young generations and notables can be defined those who have not yet displayed their virtues. This is what Cicero thinks when he says in the speech on behalf of Sestius: "I shall stir those of you young men who are notables to imitate your ancestors". Cicero, the wisest man, believes that notables are also to be designed those who could not replicate the virtues of their ancestors because of their age. And - I will express my opinion - I prefer to designate notable the man who, endowed with virtues (even if small ones), can vaunt the best ancestors than the man who excels in every kind of virtue but is of humble origins. ${ }^{61}$
\end{abstract}

In contrast to Niccoli, a representative of the class of pure intellectuals devoted to a contemplative life, Lorenzo is a man actively engaged in political life. He interprets nobility as a practical concept, a notion embracing different aspects of communal life. For Lorenzo, Cicero homo novus is a perfect example of man dominating Roman society and politics by his virtus. Yet Cicero's rhetoric of newness is integrated into a system of bourgeois values in which the debate about the nature of true nobility is only a part of a more profound reflection about human nature and the role played by the "new nobles" in the modern society. Cicero becomes then the embodiment of a concrete ideal of nobilitas, not only restricted to virtus but also enlarged to include social connections, lineage, wealthy and oratorical-political skills. ${ }^{62}$ He symbolizes the interrelationship between morality, ethics, and politics in the Italian Humanism and Renaissance. ${ }^{63}$ Most significant-

60 Niccoli's argument can be summarized in the declamatory sentence animus facit nobilem, cui ex quacumque conditione supra fortunam licet exurgere (§ 73).

61 My translation.

62 Finzi 2010, 347. On the discussion about nobility as "founded on a cultural and educational ideal”, see Rabil 1988, 3.291.

63 On politics and virtue in Renaissance Italy, see now Hankins 2019. 
ly, the Italian humanists looked at Cicero as a model to be followed by aspiring orators and politicians. Imitation and emulation of the noble deeds of the ancestors were reputed to be crucial to the formation of the modern political thought. Through and by Cicero, paradigm of political and rhetorical excellence, the humanist movement developed a new, modern ideology of nobility founded on political and social virtus, i.e., the exercise of those virtues that contribute to the growth and expansion of the civic community.

\section{Conclusion}

To sum up, from the early Empire to the Italian Renaissance Cicero is an exemplary figure of new man and new noble. As a man and intellectual acquiring a status of prestige in the society by his innate moral and political virtues, he incarnates the spirit of the new, rising nobility. In the centuries that witnessed the transformation of the early modern city-state and the development of the modern political thought, Cicero was a key figure. His personal and political deeds, worthy to be imitated by would-to-be politicians, stimulated a heated debate about the role of men of humble origins in the formation of the modern society. What is most significant, Cicero was a model for later generations of homines novi. The portrait of the ideal statesman was a Ciceronian portrait, as can be seen in the new man Niccolò Machiavelli and his depiction of Castruccio Castracani. ${ }^{64}$ To move to more recent times, the rhetoric of Cicero's newness and nobility had a profound impact on the creation of the modern democracy. The new men John Adams and Barack Obama demonstrate the vitality of Cicero's legacy and the permanence of his image of politician promoting the idea of republic relying on freedom and social mobility, in which cultural and social barriers are broken by the divine and natural laws of virtus and ingenium. ${ }^{65}$

64 Brescia 2011.

65 Samponaro 2018. On Cicero and John Adams, see Tosi 2014 (with further bibliography). See Kenty (p. 195-210) in this volume. 